\title{
The Images of Reptiles on the Items Found at the Glyadenovsky Bone Bed
}

\author{
Maria S. Koreniuk* \\ Perm State National Research University \\ 15 Bukireva Str., Perm, 614990, Russia
}

Received 21.12.2014, received in revised form 22.01.2015, accepted 06.02.2015

The article analizes one of the key images in the Old Permic art encountered in the most famous cultural site of the Kama region, the Glyadenovsky Bone Bed. The images are classified with definition of their symbolic meaning. Moreover, new recently found images are provided, which ahve not been published previously.

Keywords: ceremonial figures, bronze casting, the Glyadenovskaya culture, images, reptiles, art.

Research area: history.

\section{Introduction}

In the Early Iron Age there were unique sacred places in the Kama region - bone beds. The main part of the findings contains bones of pets and wild animals. Besides bones a lot of things were found. Over 10 artifacts of the kind have been found at the territory of the Perm region.

The central part of the bone beds usually included a site with burnt bones and ashes surrounded by significant bunching-up of crude animal bones. Different kinds of altars were also located here. Bony, bronze and iron arrow heads, beads and small round metal plates, images of birds, people, wolves and other animals made of bronze and copper are frequently found at the bone beds.

Analysis of the materials from the bone beds offers a picture of religious ideas of the Kama region population as a complex system containing various cults within it.
The most famous ceremonial altar, where different kinds of rituals meeting the ideological views of the Kama region people took place, is the Glyadenovsky Bone Bed located near the southern border of Perm city on the left bank of the Nizhniaia Mulianka river. The materials found there continue to attract many researchers studying aboriginal worldviews and cultures.

More than 30 thousand artifacts have been collected during excavation of the bone bed, and the collection does not have equals so far. One of its specific groups contains anthropomorphic and zoomorphic ceremonial figures with the total number exceeding 1 thousand images (Spitsyn, 1902, pp. 246-247; Novokreshchennykh, 1914, pp. 81-84; Lepikhin, 2007, pp. 97-98).

The purpose of this study was to analyze the images of reptiles discovered at the Glyadenovsky Bone Bed, which were found in significant amount among other ceremonial images. The article

(C) Siberian Federal University. All rights reserved

* Corresponding author E-mail address: kae.psu@gmail.com 
will give a classification of the images, their interpretation and determination of the symbolic meaning for the ancient peoples of the Kama region, as well as disposal of the discoveries that have not been presented earlier.

There are six species of reptiles in the Perm region subdivided into two subspecies: snakes and lizards (Zhivotnye Prikam'ia [Animals of the Kama Region...]..., 2001, p. 56). The figures found at the Glyadenovsky Bone Bed also contain these subspecies.

Some figures are described by A.A. Spitsyn, N.N. Novokreshchennykh and A.N. Lepikhin in their works devoted to the Glydenovsky Bone Bed. Nevertheless, the first two works were written during the pre-revolutionary period and the latter only considers the figures found before the mid-90s of the 20th century. Moreover, the works are general and this category of findings from the bone bed was not studied in detail.

\section{Main part Classification of the Images}

By the beginning of 2014, 93 artifacts were found (Koreniuk M.S., 2014, p. 290), but recently the collection has been added to by six images. 33 items out of this amount were excavated during the works in 2000s, but have not been disposed yet.

Most figures are bronze, two cast figures are soldered to the small round bronze plates, one image is engraved on the bronze small plate, 17 items are hammered out of iron.

Snakes are depicted creeping or wriggling (Fig.1) - 51 items. Such snakes can be nominally divided into intensely and slightly creeping. Moreover, the figures have some peculiarities: for example, some snakes are shown with their mouths open (Fig.1, -4,6-8,10,12), others - with their heads up.

Out of the new findings, the figure of the three-headed creeping snake is quite interesting while it represents the prototype of the threeheaded dragons (Fig. 1, -8).

The second ranked by the amount of images (38 items) are the depictions of coiling snakes (Fig. 2). Four snakes are shown with their body coiled and their head up as if ready for jumping (Fig. 2, -5-7). There are two items with bodies straight and their heads up rolling in a loop and a knot. Some snakes depicted as a spiral have an eyelet for sewing or hanging (Fig. 4) (Novokreshchenykh, 1914, p. 80).

Some compositions showing different animals with snakes have been met. In one case a bird with two snakes cast on its wing and breast, in another case a head of a bear between its paws, and a small creeping snake is soldered on its left side. In the third case, the snake is engraved above the image of a herbivore animal on the small round plate (Fig. 5, -2).

Moreover, two anthropomorphic compositional images of a human with snakes in the left hand have been found. In the first case, the snake is depicted creeping (Fig. 5, -7), in the second case it is coiling spiral (Fig. 5, -5). Moreover, a small round plate with a coiling snake in the centre should be mentioned with two anthropomorphic figures by its sides (Fig. 5, -6) (Koreniuk M.S., 2011, p. 130).

A polymorphic image of a woman-rider with three-fingered hands standing on a wolf with a snake soldered on her chest in a form of a spiral is noteworthy (Fig. 5, -4) (Koreniuk M.S., 2013, p. 94).

Images of lizards (Fig. 3) on the Glyadenovsky Bone Bed are observed only on 7 items. All of them are cast out of copper. Three lizards are depicted with short legs spread from side to side (Spitsyn, 1902, p. 248). It is noteworthy that Glyadenovsky figures of lizards are similar to those found at the Mansi sacred places but made out of lead (Lepikhin, 2007, pp. 94, 96-97). 

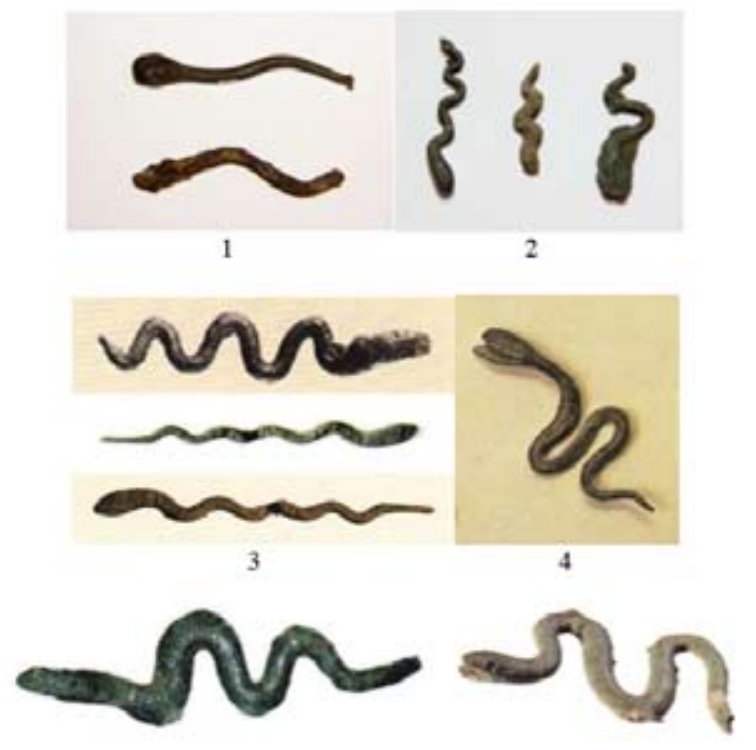

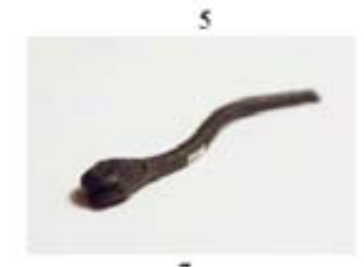

7

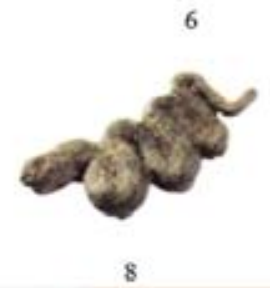

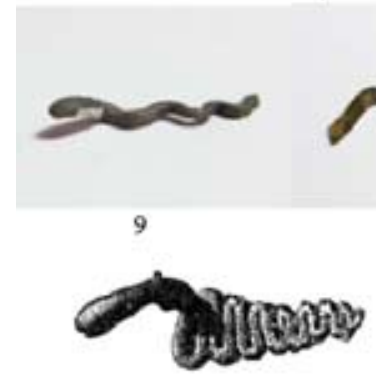

12

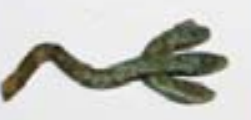

10

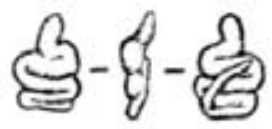

13

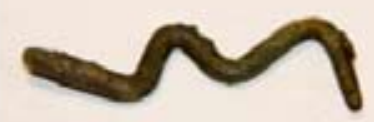

11

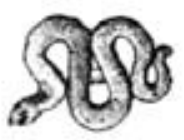

14

Fig. 1. Creeping or wriggling snakes

\section{Symbolism of the Images}

The images of snakes can be associated both with the sky (thunder, lightening, sun) and the underworld of the dead. Snakes unlike any other animals had a double nature symbolizing both good and evil beginnings.

First of all, snakes were associated with the chthonic powers. A chthonic snake is a representation of the aggressive power of the underground dark deities. The snake lives underground, therefore, it is contacting the underground world and has an access to the powers, omniscience and the magic of the dead. It has been universally considered the source of initiation and rejuvenation, as well as the host of the subsoil. In its chthonic incarnation the snake is confronting all sunny and spiritual powers symbolizing the dark powers in the human. Moreover, the positive and negative beginnings are conflicting. It is a mediator between the 


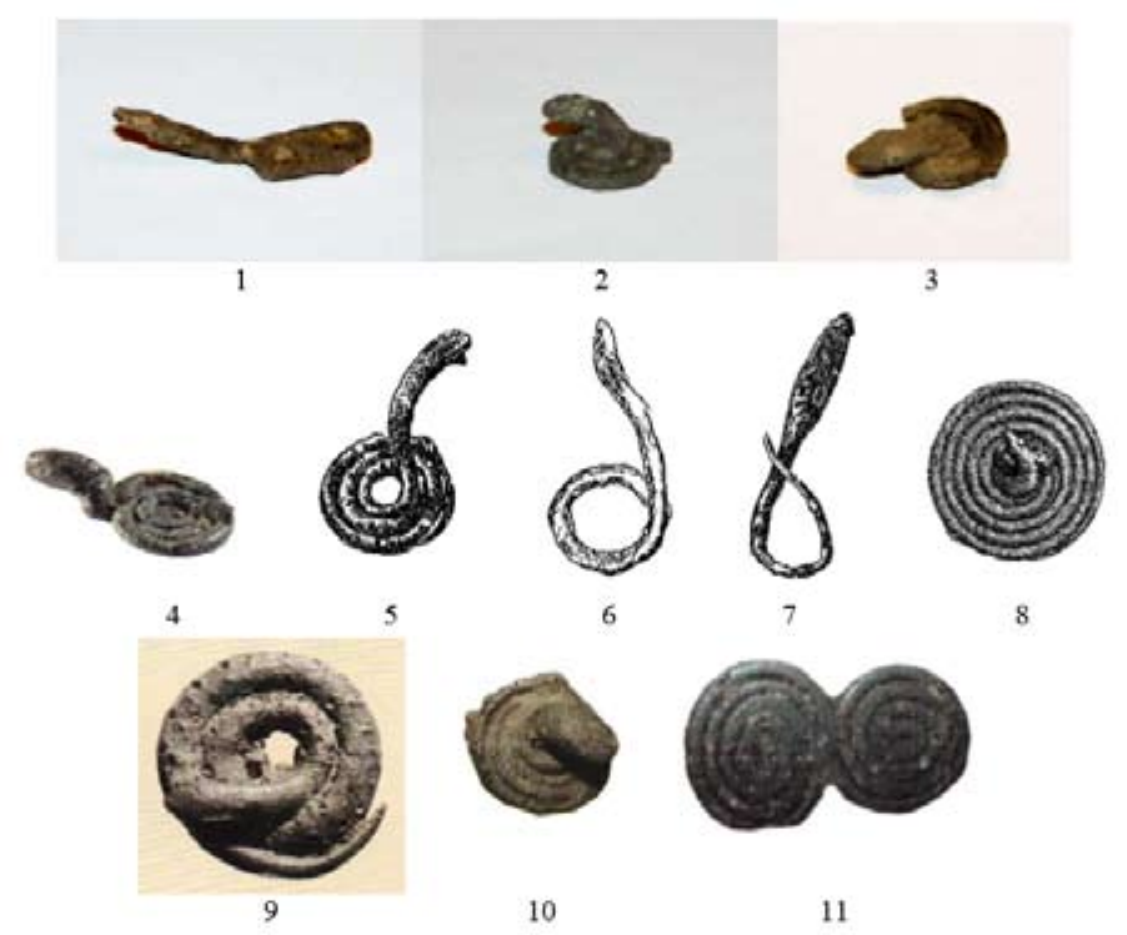

Fig. 2. Snakes coiling in a ring or in a spiral

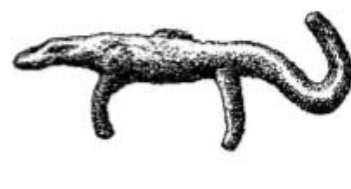

1

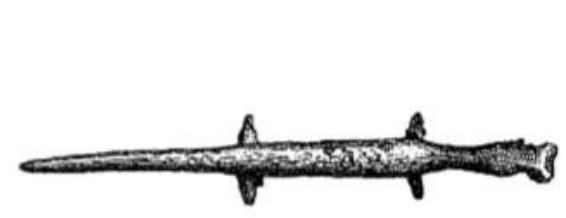

3

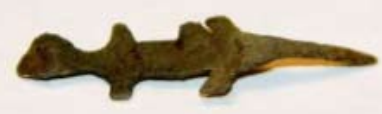

5

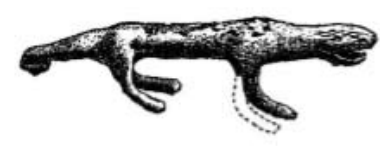

2

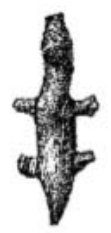

4

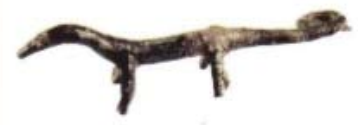

6

Fig. 3. Images of lizards 


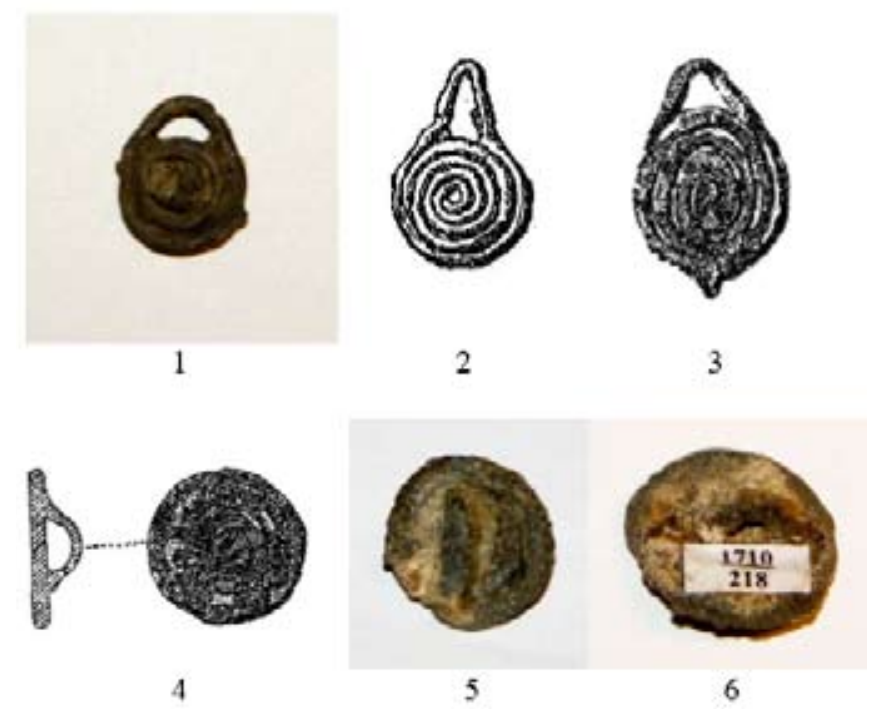

Fig. 4. Coiling snakes with an eyelet for sewing

sky and the earth, between the earth and the underground world (Cooper J., pp 106-107).

In the Kalevala, snakes and lizards comprise a fence of the Underground world, Pohjola. According to the beliefs of the Selkup people, the snake shows the way and guides the soulshadow to the world of the dead and generally symbolizes the road (Kosarev, 1981, p. 256). The connection of snakes with the water is expressed quite obviously. At the same time, the snake being an aquatic creature, was considered to be a mediator between the supreme powers living in the river upper and lower streams (Koreniuk, 2006, pp. 41-47).

The snake in the form of a zigzag (zigzag representing water) could be associated with aquatic creatures symbolizing the deity of the earth and ground waters. This deity was connected with the ideas about the "heavenly moisture" and rain. The snake was attributed the capability to attract thunderstorms, hurricanes, to get up in the sky and get down to the ground (water). The Udmurts believed in the existence of Vozho - a fiery serpent walking with an arrow in the sky (Bogaevsky, 1890, p. 99). Different ancient peoples argued that the image of the rainbow embodied the snake. Therefore, zigzags also represented the lightning. The deity of the earth (the underworld), whose symbol was the snake, could be in the sky also in the form of the moon. In one of the Udmurt tales there is a story about the serpent with the moon in the forehead and a star on the tongue (Vereshchagin, 1889, p. 188).

A coiling snake is associated with the circulation of events. It is both the solar and lunar beginnings, life and death, light and darkness, good and evil. The ornaments of many peoples include a spiral, which was a schematic depiction of the snake, and the snake was the incarnation of the deity of the underground, which was getting to the skies in the form of a lightning and initiated thunderstorms. Therefore, the spiral as well as the zigzag was the symbol of the lightening (Smirnov, 1952, p. 264).

The image of a man with a snake in his hand, apparently reflects the views of the ancient Glyadenovsky people about the path of the shaman during the ritual, when the shaman travels through the river or wood to meet a newborn's 


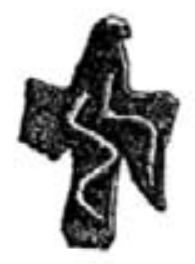

1

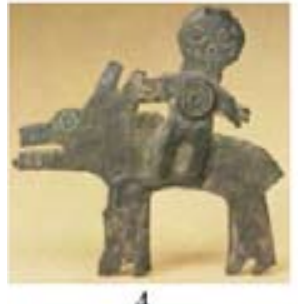

4

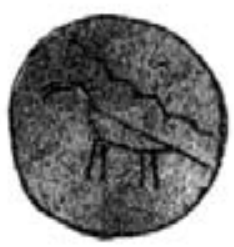

2

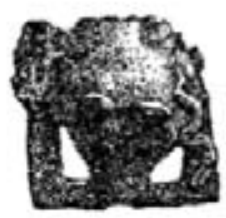

3

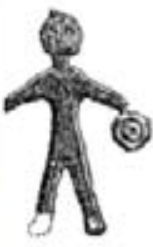

5

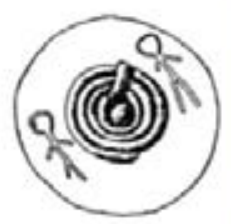

6

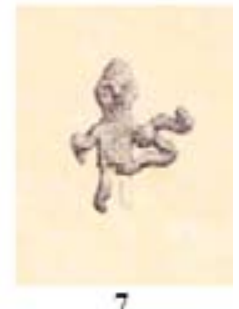

7

Fig. 5. Composite images with snakes

soul, to lead the soul of the dead or to search for the soul of the ill (Koreniuk M. S., 2012, pp. 117118), and a unique image of a woman-rider on the wolf with a snake on her chest illustrates the process of kidnapping the solar deity to the underground world.

Moreover, the snake like the lizard was considered the guard and possessor of treasures.

In Bazhov's tale based on the Urals folklore, one of the images of the Mistress of the Copper Mountain was the lizard.

In the Komi beliefs, the lizards are represented as the enemies of the Sun and, therefore, are the creatures of the chthonic world. There was a belief that the part of the body where a lizard run would rot.

In the Mansi beliefs, the lizard is also a dark creature. They believed that lizards could not be killed, while impure animals are sometimes entered by the menkv (a forest beast), which could get into the human through them. When the lizard looses its tail, this means that the menkv leaves it, thus, it is no good to see the lizard at this moment, while it is a sign of the loved one to die soon.

\section{Conclusion}

All in all, it is worth noting that the ancient Glyadenovsky people knew quite well the reptiles inhabiting the territories where they lived. Nevertheless, the reptiles were worshiped not due to their real characteristics, but as an incarnation of the deity, and herewith they have got the qualities they are associated with: wisdom, immortality, healing power etc.

By the middle of the $1^{\text {st }}$ millennium $\mathrm{AD}$ the images of snakes and lizards disappear from the territory of the Kama region, transforming into the images of other representatives of the underground world, into a complex, syncretic image of a lizard (dragon).

\section{References}

1. Bogaevsky P.M. Ocherki religioznykh predstavlenii votiakov [Essays on the Votiak Religious Beliefs] // Etnograficheskoe obozrenie [Ethnographic Review]. Moscow, 1890. Book 5, No. 2. Pp. 77-109. 
2. Cooper J. Encyclopedia of Symbols. Translated from English. Moscow, 1996, pp. 106-107.

3. Koreniuk M.S. Antropomorfnye medno-bronzovye izobrazheniia gliadenovskogo kostishcha [Anthropomorphic Copper-bronze Images of the Glyadenovsky Bone Bed] // XLIII International Ural-Volga Archeological Student Conference. Orenburg, February 1-3, 2011: materials and abstracts. Orenburg: Publishing House of the OSPU, 2011. 236 p.

4. Koreniuk M.S. Izobrazheniia presmykaiushchikhsia $v$ materialakh Gliadenovskogo kostishcha [Images of Reptiles in the Items Found at the Glyadenovsky Bone Bed] // Sovremennye problemy drevnikh $i$ traditsionnykh kul'tur narodov Evrazii [Modern Problems of Ancient and Traditional Cultures of the Peoples of Eurasia]: abstracts of LIV Regional (X All-Russian with International Participants) Archeological and Ethnographic Conference of Undergraduate and Graduate Students and Young Scientists Devoted to the $130^{\text {th }}$ anniversary of the Paleolith Discovery on the Afontovo Hill and the $100^{\text {th }}$ Anniversary the First Excavations of the Andronovskaya Culture Sites, Krasnoyarsk, March 25-28, 2014. Krasnoyarsk: Siberian Federal University, 2014. 336 p.

5. Koreniuk M.S. Simvolika antropomorfnykh izobrazhenii Gliadenovskogo kostishcha [Symbolizm of the Anthropomorphic Images of the Gladenovsky Bone Bed] // XLIV International Urals-Volga Student Conference (Yekaterinburg, February 5-9, 2012): abstract: Yekaterinburg: Publishing House of the Ural University, 2012, 212 p.

6. Koreniuk M.S. Polimorfnye obrazy $v$ iskusstve rannego zheleznogo veka Zapadnogo Priural'ia [Polymorphic Images in the Art of the Early Iron Age of the Western Urals] // XLV UralVolga Archaeological Conference of Students and Young Scientists (Izhevsk, February 1-3, 2013): abstracts, Izhevsk: Publishing house "Udmurt University", 2013. 252 p.

7. Koreniuk S.N. Obraz zmei v iskusstve i ideologii naseleniia Prikam'ia v rannem zheleznom veke [The Image of a Snake in Art and Ideology of the Kama Region Peoples in the Early Iron Age// Oborinskie chteniia [Oborin's Readings]. Materials of VI-VII Regional Archaeological Conferences (May 19, 2004 and May 24, 2005), Perm, 2006, Issue 4. Pp. 41-47.

8. Kosarev M.F. Bronzovy vek Zapadnoi Sibiri [The Bronze Age of the Western Siberia]. Moscow: Nauka, 1981. 280 p.

9. Lepikhin A.N. Kostishcha Gliadenovskoi kul'tury v Srednem I Verkhnm Prikam'e [Bone Beds of the Glyadenovskaya Culture in the Middle and Upper Kama Region]. Perm, 2007.

10. Novokreshchennykh N.N. Gliadenovskoe kostishche Permskoi gubernii na r. Kame, Permskogo uezda [The Glyadenovsky Bone Bed of the Perm Governate on the Kama River, Perm Uezd] // Trudy Permskoi uchebnoi arkhivnoi komissii [The Works of the Perm Instructional Archive Committee], 1914. Issue. XI. Pp.19-97.

11. Plesovsky F.B. Drakony v volshebnykh skazkakh i permskon zverinom stile [Dragons in the Fairy Tales and the Perm Animals Style] // Zhanr skazki v folklore naroda Komi [The Fairy Tale Genre in the Komi Folklore]. Syktyvkar, 1992. Issue. 53. Pp.6-14.

12. Smirnov A.P. Ocherki drevnei $i$ srednevekovoi istorii narodov Srednego Povolzh'ia $i$ Prikam'ia [Notes from the Ancient and Middle Age History of the Peoples of the Middle Volga Region and the Kama Region] //MIA. Moscow, 1952. No. 28. 276 p.

13. Spitsyn A.A. Gliadenovskoe kostishche [The Glyadenovsky Bone Bed] // Zapiski Russkogo arkheologicheskogo obshchestvo [The Notes of the Russian Archeological Society]. Saint Petersburg, 1902. Volume.12, Issues 1-2. Pp. 228-269. 
14. Vereshchagin G.E. Votiaki Sarapul'skogo uezda Viatskoi gub. [The Votyaks of the Sarapul'sky Uezd of the Vyatska Governate] // Zapiski russkogo geograficheskogo obshchestva [The Notes of the Russian Geographic Society]. Saint-Petersburg, 1889. V. 14. Issue 3. 197 p.

15. Zhivotnye Prikam'ia: uchebnoe posobie [The Animals of the Kama Region: Tutorial], Book 2. Perm: Knizhny mir, 2001. 168 p.

\title{
Изображения пресмыкающихся \\ в материалах Гляденовского костища
}

\author{
М.С. Коренюк \\ Пермский государственный \\ национальный исследовательский университет \\ Россия, 614990, Пермь, ул. Букирева, 15, корп. 2
}

В статье проанализирован один из ключевых образов в искусстве древнепермского населения, отображения которого найдены на самом известном памятнике Прикамья - Гляденовском костище. Приведена классификация изображений и выяснено их символическое значение. Представлены новые недавно найденные изображения, которые ранее не публиковались.

Ключевые слова: культовые фигурки, бронзовое литье, гляденовская культура, изображения, пресмыкающиеся, искусство.

Научная специиалность: 07.00.00-исторические науки. 